\title{
Lactate and stepwise lactate kinetics can be used to guide resuscitation
}

\author{
Xiang Zhou, Dawei Liu* and Longxiang Su \\ See related Letter by Thomas-Rüddel and Bauer https://ccforum.biomedcentral.com/articles/10.1186/s13054-017-1752-8
}

We thank Dr. Thomas-Rüddel for their interest in our study of stepwise lactate kinetics-oriented hemodynamic therapy. Of course, we did not find any difference between the use of inotropes and blood transfusions in our study [1]. However, the average baseline $\mathrm{ScvO}_{2}$ in our study was $72.1 \%$, a value quite similar to that of the ProCESS, ARISE, and ProMISe studies [2-4]. Therefore, a large proportion of patients in the $\mathrm{ScrO}_{2}$ group (approximately $69 \%$ of the patients in our study) could not receive future resuscitation according to the protocol, even though the average enrollment lactate levels were around $5.5 \mathrm{mmol} / \mathrm{L}$. However, the patients with high lactate levels could still enter the lactate kinetics group. An optimal resuscitation target should be able to generate sufficient driving force for the specific clinical treatment so that it can better guide the clinical therapy. Lactate, which reflects tissue hypoperfusion, has been recommended as a valuable resuscitation parameter by new Surviving Sepsis Campaign guidelines [5, 6]. Lactate kinetics, defined by Vincent $[7,8]$, represent a balance between lactate production and elimination and can represent a resuscitation parameter $[9,10]$. In our study, it was obvious that, compared with $\mathrm{ScvO}_{2}$, lactate kinetics could not only support a proper initial resuscitation, but could also guide the whole therapeutic process.

Although the lactate kinetics group were more actively resuscitated compared with the $\mathrm{ScvO}_{2}$ group, these patients received a more restrictive fluid regimen. Provided tissue perfusion was sufficient, we followed the principle of the lower the central venous pressure (CVP), the better the outcome. Many studies have demonstrated lower CVP associated with better outcome in sepsis [11, 12]. Thus, after the initial resuscitation, as the lactate kinetics targets were achieved, we tried to keep the CVP as low as possible. Even then, the lactate kinetic group still needed more fluid and had higher CVP. But compared with the trial by Jansen et al. [13], fewer crystalloid fluids were infused at each time-point, and more red blood cells were transfused in the whole process in our study. We are not sure whether this is related to the patient's prognosis. The main purpose of this stepwise lactate kinetics target-oriented therapy was to achieve effective resuscitation while avoiding overtreatment.

We strictly followed the protocol, and a patient who received the treatment of the other group was still assigned to the first group, by intention-to-treat analysis. So we did not have lactate kinetics data for the $\mathrm{ScvO} 2$ group.

As a single-center randomized controlled trial, fragility index had little influence on our study. The sample size was appropriate for both inferiority and non-inferiority trials. Additionally, we did try to strictly follow the study protocol to minimize bias. Blind testing was also used throughout the whole process of this study.

In our opinion, lactate is an important parameter for monitoring tissue perfusion at present. Lactate kinetics are particularly important to evaluate the response of ICU patients. Therefore, lactate can be the starting point for resuscitation, and monitored during the process of resuscitation to assess whether tissue perfusion is being adequately restored.

\footnotetext{
* Correspondence: dwliu98@163.com

Department of Critical Care Medicine, Peking Union Medical College

Hospital, Peking Union Medical College \& Chinese Academy of Medical

Sciences, Beijing 100730, China
}

(c) The Author(s). 2017 Open Access This article is distributed under the terms of the Creative Commons Attribution 4.0 International License (http://creativecommons.org/licenses/by/4.0/), which permits unrestricted use, distribution, and reproduction in any medium, provided you give appropriate credit to the original author(s) and the source, provide a link to the Creative Commons license, and indicate if changes were made. The Creative Commons Public Domain Dedication waiver (http://creativecommons.org/publicdomain/zero/1.0/) applies to the data made available in this article, unless otherwise stated. 
Received: 2 October 2017 Accepted: 5 October 2017

Published online: 27 October 2017

\section{References}

1. Zhou X, Liu D, Su L, Yao B, Long Y, Wang X, Chai W, Cui N, Wang H, Rui X. Use of stepwise lactate kinetics-oriented hemodynamic therapy could improve the clinical outcomes of patients with sepsis-associated hyperlactatemia. Crit Care. 2017;21(1):33.

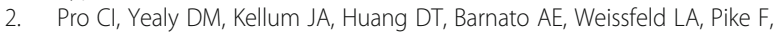
Terndrup T, Wang HE, Hou PC, et al. A randomized trial of protocol-based care for early septic shock. N Engl J Med. 2014;370(18):1683-93.

3. Investigators A, Group ACT, Peake SL, Delaney A, Bailey M, Bellomo R, Cameron PA, Cooper DJ, Higgins AM, Holdgate A, et al. Goal-directed resuscitation for patients with early septic shock. N Engl J Med. 2014; 371(16):1496-506

4. Mouncey PR, Osborn TM, Power GS, Harrison DA, Sadique MZ, Grieve RD, Jahan R, Harvey SE, Bell D, Bion JF, et al. Trial of early, goal-directed resuscitation for septic shock. N Engl J Med. 2015;372(14):1301-11.

5. Dellinger RP, Levy MM, Rhodes A, Annane D, Gerlach H, Opal SM, Sevransky JE, Sprung CL, Douglas IS, Jaeschke R, et al. Surviving Sepsis Campaign: international guidelines for management of severe sepsis and septic shock, 2012. Intensive Care Med. 2013:39(2):165-228.

6. Rhodes A, Evans LE, Alhazzani W, Levy MM, Antonelli M, Ferrer R, Kumar A, Sevransky JE, Sprung CL, Nunnally ME. Surviving Sepsis Campaign: international guidelines for management of severe sepsis and septic shock, 2016. Intensive Care Med. 2017:43(3):304-77.

7. Vincent $\mathrm{J}$. Serial blood lactate levels reflect both lactate production and clearance. Crit Care Med. 2015;43(6), e209.

8. Vincent JL. Lactic acidosis. N Engl J Med. 2015;372(11):1077-8.

9. Jones AE, Shapiro NI, Trzeciak S, Arnold RC, Claremont HA, Kline JA. Emergency Medicine Shock Research Network (EMShockNet) Investigators. Lactate clearance vs central venous oxygen saturation as goals of early sepsis therapy: a randomized clinical trial. JAMA. 2010;303(8):739-46.

10. Walker CA, Griffith DM, Gray AJ, Datta D, Hay AW. Early lactate kinetics in septic patients with elevated lactate levels admitted from the emergency department to intensive care: time to aim higher? J Crit Care. 2013;28(5): 832-7.

11. Boyd JH, Forbes J, Nakada TA, Walley KR, Russell JA. Fluid resuscitation in septic shock: a positive fluid balance and elevated central venous pressure are associated with increased mortality. Crit Care Med. 2011;39(2):259-65.

12. Yamada $H$, Tsukamoto $T$, Narumiya $H$, Oda K, Higaki S, lizuka R, Yanagita M, Deguchi M. Initial central venous pressure could be a prognostic marker for hemodynamic improvement of polymyxin B direct hemoperfusion: a retrospective cohort study. J Intensive Care. 2016;4:64.

13. Jansen TC, van Bommel J, Schoonderbeek FJ, et al. Early lactate-guided therapy in intensive care unit patients: a multicenter, open-label, randomized controlled trial. Am J Respir Crit Care Med. 2010;182(6):752-761. 